\title{
The Effectiveness of Homemade Soymilk in Increasing Haemoglobin (Hb) Levels in Pregnant Women
}

\author{
${ }^{1}$ Teungku Nih Farisni, ${ }^{1}$ Fitriani Fitriani, ${ }^{3}$ Yarmaliza Yarmaliza \\ ${ }^{1}$ Faculty of Public Health, Teuku Umar University, Aceh, Indonesia \\ Corresponding author's email: teungkunihfarisni@utu.ac.id
}

Submitted: 17/08/2019 Revised: 21/09/2019 Accepted: 04/10/2019

How to cite this article:

Farisni, T., Fitriani, F., \& Yarmaliza, Y. (2019). The effectiveness of homemade soymilk in increasing haemoglobin ( $\mathrm{Hb}$ ) levels on pregnant women. J-KESMAS, 6(2), 41- 48

\begin{abstract}
The high prevalence of anaemia in pregnant women in West Aceh Regency (40.5\%), which is indicated by the haemoglobin $(\mathrm{Hb})$ levels of below $11 \mathrm{~g} \%$, should receive special attention because anaemia will have an impact on maternal and infant mortality. Soymilk is one processed beverage that contains iron, high protein, essential fatty acids, fibre, vitamins and minerals. Nutrients contained in soy can produce energy, maintain optimal body functions, and meet the needs of iron in pregnant women. Soybean is a type of food which is ranked third to have the richest iron $(8.8 \mathrm{mg} \%)$ after meat and cereals. The purpose of this study was to examine the effectiveness of homemade soymilk in increasing Hb levels in pregnant women. The study design was an experiment on pregnant women. The object of this study was pregnant women in their first and second trimester of pregnancy. The intervention was giving homemade soymilk by adding $10 \mathrm{ml}$ of honey, as a substitute for sugar, to 1 cup of homemade soymilk $(250 \mathrm{ml})$, from a basic intake of $4 \mathrm{mg}$ of iron per day for pregnant women. This intervention resulted in a significant increase in $\mathrm{Hb}$ levels in pregnant women $(\mathrm{P}<0.005)$. The provision of homemade soymilk can significantly increase the mean of $\mathrm{Hb}$ levels in pregnant women with an average increase of $2.99 \mathrm{mg} \%$ \pm 1.422 . Furthermore, the $p$-value obtained was $=0.000$, indicating that there was a significant difference in $\mathrm{Hb}$ levels between measurement I (before being given homemade soymilk) and after being given homemade soymilk for 3 months. Homemade soymilk is an effective drink in increasing $\mathrm{Hb}$ levels in pregnant women.
\end{abstract}

\section{Keywords}

Milk; soybean; Hb levels; pregnant women

\section{Introduction}

Malnutrition in the world reaches $2 \times 106$ to $3.5 \times 106$ million people per year. One of the malnutrition cases is iron deficiency (anaemia) in pregnant women. Anaemia is a major public health problem in developing countries and takes decades to overcome (Chakrabarti, 2019). 
The world health assembly is targeting 50\% reduction in anaemia in productive women (19-45 years) from 2012 to 2025(3) (WHO, 2015).

Anaemia in pregnancy is a state of decreased haemoglobin $(\mathrm{Hb})$ levels of less than $12 \mathrm{~g} \%$. Anaemia in pregnant women is a health problem that should get special attention because it has an impact on maternal and infant mortality. The results of Basic Health Research show that there were $37.1 \%$ cases of anaemia in pregnant women in Indonesia in 2013 and it increased to $48.9 \%$ in 2018 . In Aceh Province, the prevalence of anaemia was $39.2 \%$ in 2017 and increased to $44.6 \%$ in 2018. The Health Office of West Aceh Regency notes that cases of anaemia in pregnant women in 2018 increased by $40.5 \%$.

This significant increase in anaemia cases results in the increase of maternal and infant mortality cases per year. The need for iron in pregnant women increases compared to nonpregnant women. The average need for iron in pregnant women is $800-1040 \mathrm{mg}$. The incidence of anaemia in pregnant women occurs in the second and third trimester (70\%). This problem needs special handling in order to fulfil the need for iron in pregnant women at this point of time.

Some foods that can increase iron intake are meat $(23.8 \mathrm{mg})$, cereal $(18 \mathrm{mg})$, soybean $(8.8 \mathrm{mg})$, bean $(8.3 \mathrm{mg})$, rice $(8 \mathrm{mg})$, spinach $(6.4 \mathrm{mg})$, hamburger $(5.9 \mathrm{mg})$, beef liver $(5.2 \mathrm{mg})$, and formula milk $(1.2 \mathrm{mg})$. Soybean ranks third in iron after meat and cereals by $8.8 \mathrm{mg}$. Soymilk is one of the processed drinks from soy and one of the additional supplements that contain iron, high protein, essential fatty acids, protein, fibre, vitamins and minerals. The nutrients contained in soy can produce energy and maintain optimal body function. Soymilk in an important alternative for human nutrition. Referring to the content, soymilk can be a sufficient iron source to reduce anaemia.

Research states that drinks fortified with additional nutrients such as calcium, iron, phosphorus, potassium, and magnesium is proven to reduce iron deficiency (anaemia) in pregnant women (Zhenyu, 2011). The purpose of this study was to examine the effectiveness of homemade soymilk in increasing $\mathrm{Hb}$ levels in pregnant women.

\section{Literature Review}

Soybean is a plant that contains elements and nutrients that are important for our body. Soybean is one kind of food that has high nutrient content, such as protein and carbohydrates. Soybean is also relatively affordable and widely consumed by the community, so it is better to increase the fortification of nutrients in soybean. Soybean consists of 7.3 percent skin, 90.3 percent cotyledon (the bean) and 2.4 percent hypocotyl. Soybean contains an average of 35 percent protein, even in superior varieties the protein content can reach 40-44 percent. Soy protein mostly ( 85 - 95 percent) consists of globulin and compared to other beans, the composition of amino acids in soybean is more complete and balanced. Soybean contains about 18-20 percent fat and 25 percent of it consists of unsaturated fatty acids that are cholesterol free. In addition, soybean fat contains several important phospholipids, namely lecithin, cepalin and lipositol.

Soymilk is one of the processed drinks from soy and one of the additional supplements that contain high protein. Soymilk is a nutritious drink made from soybeans. Soymilk contains essential fatty acids, protein, fibre, vitamins and minerals. The nutrients contained in soy can produce energy and maintain optimal body function. Soymilk, an important alternative for human nutrition, is based on soy protein extracts that are hydrolysed with water. In this way, 
soymilk can be sufficient iron to reduce anaemia. Soymilk protein can be used as a substitute for cow's milk for those who are allergic to lactose (lactose intolerance) or for those who don't like cow's milk. To get good soymilk that is suitable for human consumption, the following requirements are needed: free from the smell and taste of soybean, free of antitrypsin, and have good colloidal stability.

\section{How to Make Soymilk}

Soymilk can be made using simple technology and equipment that does not require high skills, or with modern technology in the factory. Today there are many ways that can be used to make soymilk with good results. The following is the process of making soybean milk in a simple, appropriate manner with simple equipment, making it suitable for household and small-scale industries. The stages in the making are as follows:

1. Soybeans that have been sorted (separated from impurities and broken seeds) are soaked in a solution of $\mathrm{NaHCO} 3$ or baking soda $0.25-0.5$ percent for 30 minutes.

2. The soybeans are drained, added new water, and then boiled them for 30 minutes. The soybean skins then are separated by kneading and washing with water several times (the skin will be easily separated).

3. The soybeans are ground with a metal grinder, or a stone grinder (which is commonly used in making tofu), or a blender.

4. The slurry obtained is added with boiling water until the total amount of water reaches 10 times the weight of dried soybeans.

5. The dilute slurry is filtered with gauze and the filtrate is raw soymilk.

6. To improve the taste and acceptance, 7 - 15 percent sugar and enough essence, such as chocolate, mocha, pandan or strawberries (can be bought at cake shops, supermarkets or chemical stores), are added to raw soybean milk, then heated to boiling.

7. After boiling, the heat is reduced and left on low heat for 20 minutes.

8. When it is bottled, CMC can be added to $100 \mathrm{ppm}$ of soymilk (100 $\mathrm{mg}$ of CMC is added to 1 litre of soymilk). The soymilk should be in a cold temperature around 50C (refrigerator temperature).

\section{Anaemia in Pregnant Women}

According to Saifudin, anaemia in pregnant women is a condition of pregnant women with $\mathrm{Hb}$ levels below $11 \mathrm{gr} \%$ in trimesters I and III or Hb levels are less than $10.5 \mathrm{gr} \%$ in trimester II. Meanwhile, anaemia in non-pregnant women occurs when their $\mathrm{Hb}$ levels are less than $12 \%$ gr. The anaemia that is mostly found in pregnancy is due to iron $(\mathrm{Fe})$ deficiency. This deficiency can be caused by the lack of iron intake due to impaired absorption, disruption of use or too much iron out of the body, for example in bleeding. The need for iron increases in pregnancy, especially in the second and third trimesters due to the increasing need for the foetus in the womb. If the iron intake is not increased during pregnancy, iron deficiency is easy to occur, especially in twin pregnancy.

In general, there are three causes of anaemia in pregnant women:

1. Chronic blood loss, as a result of chronic bleeding such as peptic ulcer disease, haemorrhoids, parasitic infestations and malignancy.

2. Inadequate iron intake and inadequate absorption.

3. Increasing need for iron for the formation of red blood cells which is common during infancy, puberty, pregnancy and lactation (8). 
To establish the diagnosis of anaemia in pregnant women, a haemoglobin test and monitoring can be done by Sahli's haemoglobinometer. Haemoglobin test results can be classified as follows:

1. $\mathrm{Hb}>11 \mathrm{gr} \%$ is called no anaemia.

2. $\mathrm{Hb} 9-10 \mathrm{gr} \%$ is called mild anaemia.

3. $\mathrm{Hb} 7-8 \mathrm{gr} \%$ is called moderate anaemia.

4. $\mathrm{Hb}<7 \mathrm{gr} \%$ is called severe anaemia.

The amount of iron needed in pregnant women is far greater than in non- pregnant women. In the first trimester of pregnancy, the need for iron is not much because there is no menstruation and foetal growth is slow. Meanwhile, in the second and third trimester of pregnancy, there is an increase in red blood cells up to $35 \%$ which is equivalent to $450 \mathrm{mg}$ of iron. This increase is caused by the increasing oxygen demand by the foetus that must be transported by red blood cells. Then during childbirth, blood loss will occur, and a 300-350 mg iron will be required. It is estimated that from pregnancy to childbirth, it needs more or less $40 \mathrm{mg}$ iron per day or twice from the need during normal conditions (not pregnant). Not surprisingly, many pregnant women end up suffering from anaemia due to the increasing need for iron, but their food consumption does not fulfil it.

Anaemia in pregnancy can directly or indirectly cause maternal death by $15-20 \%$. This condition causes an increasing frequency of pregnancy and labour complications, maternal death risks, prematurity, low birth weight (LBW) and perinatal mortality rates. It is also risky for antepartum and postpartum haemorrhage. It is also highly likely that pregnant women who suffer from anaemia experience many disorders, such as easily to faint, experience miscarriage, or undergo prolonged labour due to poor contractions.

\section{Method}

The method of this study was experimental study which determined the effectiveness of the provision of homemade soymilk to increase the $\mathrm{Hb}$ levels in pregnant women by giving treatment. The population in this study were all pregnant women in the District of Seunagan, Nagan Raya Regency. The sampling technique was purposive sampling. The sample of this research was 20 pregnant women in their first and second trimester. The criteria of the sample in this study were mothers who were willing to get treatment for 3 months, the first and second trimester pregnant women, and those who lived in Seunagan District, Nagan Raya.

The steps of this research were as follows.

1. The pregnant women were given an informed consent to be willing to get treatment for 3 months.

2. The pregnant women and health cadres were trained to make homemade soymilk.

3. The research assistants measured the Hb levels of the pregnant women using Sahli's $\mathrm{Hb}$ measurement method before giving them homemade soymilk.

4. The research assistant monitored the pregnant women in the process of homemade soymilk consumption.

5. The research assistants measured blood levels fortnightly to obtain the results after consuming homemade soymilk.

6. The provision of homemade soymilk by adding $10 \mathrm{mg}$ of honey to 1 cup homemade soymilk as a substitute for granulated sugar. 
The instrument used was a data observation sheet. Then, the data obtained were analysed by using univariate statistical analysis to describe the frequency distribution of variables, then bivariate analysis was done by using paired sample t-test.

\section{Results}

From the study on 20 pregnant women who were given homemade soy milk intervention with the addition of $10 \mathrm{mg}$ of honey in 1 serving glass (equivalent to $250 \mathrm{ml}$ ) once a day for 3 months and got their $\mathrm{Hb}$ levels measured fortnightly, six respective measurements were obtained which were named measurement I, II , III, IV, V, VI. From the results of those measurements, the mean obtained were $9.5 \pm 1.35,10.85 \pm 1.22,11.15 \pm 0.7,11.65 \pm 8.88,11.45 \pm 1.15,12.51 \pm$ 1.06 respectively. The data is also presented in the Table 1 below:

Table 1. The mean of the differences of the Hb level on the pregnant women based on the measurement

\begin{tabular}{cccccc}
\hline $\begin{array}{c}\text { Hb Level } \\
\text { Measurement }\end{array}$ & Month & $\mathrm{N}$ & $\begin{array}{c}\text { Mean } \pm \\
\text { Standard } \\
\text { Deviation } \\
(\mathrm{mg} \%)\end{array}$ & $\begin{array}{c}\text { Anaemia } \\
(\mathrm{Hb} \text { level }< \\
11 \mathrm{mg} \%)\end{array}$ & $\begin{array}{c}\text { Non } \\
\text { anaemia }(\mathrm{Hb} \\
\text { level }>11 \\
\mathrm{mg} \%)\end{array}$ \\
\hline Measurement I & 1 & 20 & $9.5 \pm 1.35$ & 16 & 4 \\
\hline $\begin{array}{c}\text { Measurement } \\
\text { II }\end{array}$ & 1 & 20 & $10.85 \pm 1.22$ & 13 & 7 \\
\hline $\begin{array}{c}\text { Measurement } \\
\text { III }\end{array}$ & 2 & 20 & $11.15 \pm 0.7$ & 6 & 14 \\
\hline $\begin{array}{c}\text { Measurement } \\
\text { IV }\end{array}$ & 2 & 20 & $11.65 \pm 8.88$ & 3 & 17 \\
\hline $\begin{array}{c}\text { Measurement } \\
\text { V }\end{array}$ & 3 & 20 & $11.45 \pm 1.15$ & 6 & 14 \\
\hline $\begin{array}{c}\text { Measurement } \\
\text { VI }\end{array}$ & 3 & 20 & $12.51 \pm 1.06$ & 0 & 20 \\
\hline
\end{tabular}

Measurement I was the measurement of the $\mathrm{Hb}$ levels of pregnant women before consuming homemade soymilk, and the mean obtained was $9.5 \pm 1.35$. The description of $\mathrm{Hb}$ levels of pregnant women was that most of them experienced anaemia because their Hb levels were below $11 \mathrm{mg} \%$ in the second measurement (II) of their $\mathrm{Hb}$ levels, the women who have consumed homemade soymilk for 2 weeks got their $\mathrm{Hb}$ levels increased by $1.35 \mathrm{mg} \%$. Look at Table 2 below for the mean difference in the $\mathrm{Hb}$ levels.

Table 2. The mean of difference in the Hb levels in pregnant women before and after intervention

\begin{tabular}{ccccc}
\hline $\begin{array}{c}\text { Hb level } \\
\text { measurement }\end{array}$ & $\mathrm{N}$ & $\begin{array}{c}\text { Mean } \pm \text { Standard } \\
\text { Deviation }(\mathrm{mg} \%)\end{array}$ & $\begin{array}{c}\text { The Mean of the } \\
\text { Hb level } \\
\text { increased. }\end{array}$ & P-Value \\
\hline $\begin{array}{c}\text { Hb level } \\
\text { measurement } \\
\text { before }\end{array}$ & 20 & $9.5 \pm 1.35$ & & \\
intervention & & & $2.99 \pm 1.422$ & 0.000 \\
\hline
\end{tabular}




\begin{tabular}{cc}
\hline Hb level & \\
measurement & \\
after 3 & $12.51 \pm 0.83$ \\
months & \\
intervention & \\
\hline
\end{tabular}

Based on the Table 2. Above, there was a significant difference between the Hb levels on measurement I (before intervention) and the $\mathrm{Hb}$ levels after the intervention or after the pregnant women were being given homemade soy milk for 3 months ( $p$-value $=0,000$ ) with the mean of the increased $\mathrm{Hb}$ levels of $2,99 \mathrm{mg} \% \pm 1,422$.

\section{Discussion}

The mean of the $\mathrm{Hb}$ levels in pregnant women who was given homemade soymilk fortified with honey could significantly increase. In the treatment group, iron was obtained merely from the rice they consumed daily and homemade soymilk with the addition of honey.

In the first measurement (Measurement I), the mean of the Hb levels of the pregnant women was $9.5 \mathrm{mg} \%$ and it was also indicated that most of them suffered from anaemia or iron deficiency $(80 \%)$. In the second measurement (Measurement II), however, after being given homemade soymilk fortified with honey for 2 weeks, the mean increased to $10.2 \mathrm{mg} \%$ along with the decreasing percentage of the number of pregnant women suffering from anaemia by $65 \%$. In the third (III) and fourth (IV) measurements, the mean of the Hb levels also increased, but in the fifth measurement (V), the number slightly dropped from $11,65 \mathrm{mg} \%$ to $11,45 \mathrm{mg} \%$. The cause of this decline was likely due to the increasing need for iron every week and may due to other disruptive factors experienced by respondents. However, in the sixth measurement (VI), the mean increased to $12.51 \mathrm{mg} \%$.

Statistical test results showed that there was a significant rise in the mean of the $\mathrm{Hb}$ levels in pregnant women after consuming homemade soymilk for 3 months, (p-value $=0,000)$, with an increase in their $\mathrm{Hb}$ levels of $2.99 \mathrm{mg} \% \pm 1.422$. There was therefore a significant distinction in the mean of the $\mathrm{Hb}$ levels of pregnant women before and after intervention.

Homemade soymilk added with honey can assist to meet the nutrition need of pregnant women, especially the need for iron and protein in order to avoid anaemia in pregnant women. Both Soymilk and honey contain $8.8 \mathrm{mg} \%$ and $0.9 \mathrm{mg} \%$ iron respectively. Honey added to homemade soymilk is as a substitute for sugar since honey is healthier. Furthermore, besides that honey is also a source of vitamins and minerals, it is also easily digested by the most sensitive stomach, thus it is suitable to be consumed by pregnant women.

Iron deficiency can cause a decrease in cognitive development in the fetus and an impaired immune function during pregnancy. A number of studies also showed that soy and honey contain iron which is needed by pregnant women. Moreover, other researches also stated that a healthy pregnancy can increase pregnant women's and fetuses' weight with the lowest risk of complications during pregnancy and delivery. A healthy pregnancy can be achieved by consuming foods that contain nutrition needed by pregnant women. Thus, pregnant women should limit the food containing fat or sugar to prevent obesity, and it is recommended for them to consume food that contain protein and iron which can be obtained from meat, cereal and nuts. 
The results of a study by Astuti, (2014) showed that soybeans that had been processed into tempeh could have higher level of iron even though not in significant amount. In raw tempeh, the iron levels in each treatment increased by $90 \mathrm{mg}, 110 \mathrm{mg}, 130 \mathrm{mg}$ and $150 \mathrm{mg}$ per $1 \mathrm{~kg}$ of wet soybean making its iron level per 100 gram tempeh increased to $3.46 \mathrm{mg}, 3.45 \mathrm{mg}, 3.57$ $\mathrm{mg}$ and $4.32 \mathrm{mg}$ respectively.

Novianti's (2019) study showed the result of soybean milk intake data between two groups and its significant difference in the protein $(p=0,000)$ and iron intake $(p=0,000)$, but there was no significant difference in vitamin $\mathrm{C}$. In accordance to the study mentioned, pregnant women need to consume more foods containing vitamin C, B12, folic acid and protein to increase the absorption of iron in the body and avoid consuming food containing iron along with those which inhibit the absorption of iron such as tea and coffee.

The results of a study also showed that the provision of soymilk to female teenagers could increase their $\mathrm{Hb}$ level. In her study, Fatimah concluded that soybean was quite effective to increase Hemoglobin in the body and it was also a convenient source of food, easy to obtain, and save to be an alternative for healthy dish.

Research done by Utomo (2012) show the impact of soy provision in increasing $\mathrm{Hb}$ levels in rats, where the group that was given nutrients from soy had higher $\mathrm{Hb}$ levels compared to group that was not given. The nutrient doses from soybean are positively correlated to increase $\mathrm{Hb}$ levels. Soybean contains iron, protein, and vitamin $\mathrm{C}$ which play a role in the process of erythropoiesis.

Soymilk is one supplement drink that can meet nutritional needs and can maintain a fit body condition to be not easily attacked by diseases. The form of fresh milk (soymilk) contains nutrients, including iron, calcium, carbohydrates, vitamin A and vitamin B complex, which are quickly absorbed and needed by the human body, especially by pregnant women. In this study, it was obtained that homemade soymilk added with honey is very effective in increasing the $\mathrm{Hb}$ levels of pregnant women. The addition of honey enriched the nutrients in the soymilk consumed by pregnant women and is suitable for pregnant women's condition considering they must reduce sugar intake during their pregnancy.

\section{Conclusion}

The provision of homemade soymilk can significantly increase the mean of $\mathrm{Hb}$ level in pregnant women with an average increase in $\mathrm{Hb}$ level of $2.99 \mathrm{mg} \% \pm 1.422$. The p-value obtained was 0,000 which indicated that there was a significant difference between $\mathrm{Hb}$ levels in measurement I or measurements before being given homemade soymilk with $\mathrm{Hb}$ levels after being given homemade soymilk for 3 months.

\section{Acknowledgment}

This research was funded by the Teuku Umar University Internal Grant, we hereby thank the Institute of Research and Community Service of Teuku Umar University which have supported this research and also we would like to thank the pregnant women who are willing to be participate as the respondents and all parties who involved in this study.

\section{Author Contribution and Competing Interest}


All of the authors contributed in collecting and analyzing the data, including preparing the manuscript. The first author acted as the chief researcher and as the corresponding author. The second and the third author acted as members of researchers helping the first author in collecting and analyzing the data. There was no competing interest related to the conduct of this study.

\section{References}

Advances in Nutrition. Iron 1. Am Soc Nutr Adv Nutr [Internet]. 2012;3:(1):532-3. Available from:

http://eds.b.ebscohost.com.ezproxy.endeavour.edu.au/eds/pdfviewer/pdfviewer?vid=25 \&sid=d7c1ae22-bf65-4e2f-b282-807977ba9940\%40sessionmgr115\&hid=117

Astuti R., Aminah S., \& Syamsianah A. (2014). Komposisi Zat Gizi Tempe Yang Difortifikasi Zat Besi Dan Vitamin A Pada Tempe Mentah Dan Matang (Nutritional Composition of Soyben Tempeh Fortified with Iron and Vitamin A on Uncook and Cook Soyben Tempeh). Agritech. 34(2), 151-9.

Budimarwant, C. (2017). Komposisi dan nutrisi pada susu kedelai. Compotition Nutrition, 17.

Chakrabarti S., Kishore A., Raghunathan K., \& Scott SP. (2019). Impact of subsidized fortified wheat on anaemia in pregnant Indian women. Maternal Child Nutrition, 15(1), 1-11.

Utomo, G. (2012). Pengaruh Pemberian Nutrisi Kedelai Terhadap Peningkatan Kadar Hemoglobin Tikus Strain Wista Anemia. Journal of Chemical Information and Modeling.

Yang Z, \& Huffman SL. (2011). Review of fortified food and beverage products for pregnant and lactating women and their impact on nutritional status. Maternal Child Nutrition, $7(3), 19-43$.

WHO. (2015). Comprehensive implementation plan on maternal, infant and young child nutrition. 